\title{
Molecular Variants in Human Trace Amine-Associated Receptors and Their Implications in Mental and Metabolic Disorders
}

\author{
Grazia Rutigliano $^{1,2} \cdot$ Riccardo Zucchi $^{3}$ (i)
}

Received: 19 July 2019 / Accepted: 2 October 2019 / Published online: 23 October 2019

(c) The Author(s) 2019

\begin{abstract}
We provide a comprehensive review of the available evidence on the pathophysiological implications of genetic variants in the human trace amine-associated receptor (TAAR) superfamily. Genes coding for trace amine-associated receptors (taars) represent a multigene family of G-protein-coupled receptors, clustered to a small genomic region of $108 \mathrm{~kb}$ located in chromosome $6 \mathrm{q} 23$, which has been consistently identified by linkage analyses as a susceptibility locus for schizophrenia and affective disorders. Most TAARs are expressed in brain areas involved in emotions, reward and cognition. TAARs are activated by endogenous trace amines and thyronamines, and evidence for a modulatory action on other monaminergic systems has been reported. Therefore, linkage analyses were followed by fine mapping association studies in schizophrenia and affective disorders. However, none of these reports has received sufficient universal replication, so their status remains uncertain. Single nucleotide polymorphisms in taars have emerged as susceptibility loci from genome-wide association studies investigating migraine and brain development, but none of the detected variants reached the threshold for genome-wide significance. In the last decade, technological advances enabled single-gene or whole-exome sequencing, thus allowing the detection of rare genetic variants, which may have a greater impact on the risk of complex disorders. Using these approaches, several taars (especially taarl) variants have been detected in patients with mental and metabolic disorders, and in some cases, defective receptor function has been demonstrated in vitro. Finally, with the use of transcriptomic and peptidomic techniques, dysregulations of TAARs (especially TAAR6) have been identified in brain disorders characterized by cognitive impairment.
\end{abstract}

Keywords Trace amine-associated receptors $\cdot$ Genetics $\cdot$ Schizophrenia $\cdot$ Bipolar disorder $\cdot$ Single nucletide polymorphism

\section{Introduction}

Trace amine-associated receptors (TAARs) belong to the family of G-protein-coupled receptors (GPCRs) (Zucchi et al. 2006; Grandy 2007). GPCRs, also known as seventransmembrane receptors, represent the most versatile family of membrane receptors, as they respond to a broad range of stimuli, such as light, odorants, hormones, and several types of chemical messengers, including neurotransmitters (Pierce et al. 2002). The presence of a DRY motif (i.e.

Grazia Rutigliano

grazia.rutigliano@santannapisa.it

1 Institute of Life Sciences, Sant'Anna School of Advanced Studies, Piazza Martiri della Libertà 33, 56127 Pisa, Italy

2 Institute of Clinical Physiology, National Research Council, Pisa, Italy

3 Department of Pathology, University of Pisa, Pisa, Italy aspartate-arginine-tyrosine: unless otherwise specified, we are using single letter codes for amino acid residues) in the third transmembrane domain allocates TAARs to the largest class of GPCRs, known as Class A or Rhodopsin-like family (Borowsky 2001).

In mammals, the genes coding for TAARs (henceforward indicated as taars) are characterized by high homology, all cluster in a small region of a unique chromosome, with consistent transcriptional orientations across orthologs (Lindemann et al. 2005). All members of the taar family generate short ( 1000-bp-long) intronless transcripts, with the exception of taar2 which contains two exons. According to molecular evolutionary analyses, an ancestral gene emerged in the see lamprey (Eyun et al. 2016). Then, several species-specific events of gene duplications and pseudogenizations occurred, so that the number of taars is highly diverse among mammals, ranging from 0 in dolphins to 26 in the flying fox (Eyun et al. 2016). The receptors are classified into nine subfamilies (TAAR1 to TAAR9) (Hashiguchi 
and Nishida 2007). The oldest subfamily includes TAAR1, which is the only TAAR that is not expressed in the olfactory epithelium and does not function as an olfactory receptor (Eyun et al. 2016). Therefore, it appears that the divergence of younger TAARs from TAAR1 was accompanied by a change in their expression pattern (Eyun et al. 2016). From the functional point of view, receptors in the TAAR1-4 cluster detect primary amines, while those in the TAAR5-9 cluster, which are specific to therian mammals, are predominantly stimulated by tertiary amines (Ferrero et al. 2012).

While most genomes contain a single well-conserved copy of the more anciently emerged taar subfamily genes (taar 1-4), the latest subfamilies (taar5-9) underwent multiple species-specific duplications, with positive selection, e.g. in $\operatorname{taar} 7$ (Eyun et al. 2016). On the contrary, primate genomes are characterized by a small number of taars, with accelerated pseudogenization of taar repertoires (Eyun 2018). In particular, the human genome encompasses six taars, all present as single-copy genes, and mapping to a small genomic region of $108 \mathrm{~kb}$ located in chromosome 6q23 (Vladimirov et al. 2007). Functional TAAR3, TAAR4, and TAAR7 have been lost (Lindemann et al. 2005; Eyun et al. 2016), before humans diverged from gorillas (Fig. 1) (Staubert et al. 2010).

TAARs were identified while searching for novel biogenic amine receptors, but turned out to respond to trace amines, instead (Borowsky 2001; Bunzow 2001). The term trace amines refers to endogenous amines, namely $\beta$-phenylethylamine, $p$-tyramine, tryptamine, octopamine, and synephrine. They derive from aromatic amino acids and are physiologically present in tissues at much lower concentrations ( $<100 \mathrm{ng} / \mathrm{g}$ tissue) (Boulton 1974) than the classic biogenic amines, such as dopamine, serotonin, norepinephrine, and histamine. While trace amines are major chemical messengers in invertebrates, in mammals they were originally believed to act as "false transmitters", i.e. displacing classic biogenic amines from their stores and inhibiting their transporters (Parker and Cubeddu 1986). With the discovery of TAARs, it became clear that trace amines may exert actions in their own respect (Borowsky 2001; Berry 2004; Geracitano et al. 2004). Furthermore, some TAARs (notably TAAR1 and TAAR5) bind with high affinity to another class of endogenous amines, i.e. thyronamines, probably representing a novel branch of thyroid hormone signalling (Scanlan et al. 2004; Zucchi et al. 2014; Hoefig et al. 2016; Kohrle and Biebermann 2019). As a matter of fact, binding to trace amines has not been demonstrated for all TAAR subtypes, and this is the reason why the acronym TAAR has been accepted by the Human Genome Organization (HUGO) Gene Nomenclature Committee, although the International Union of Pharmacology (IUPHAR) still recommends the original denomination of trace amine receptors (Maguire et al. 2009).
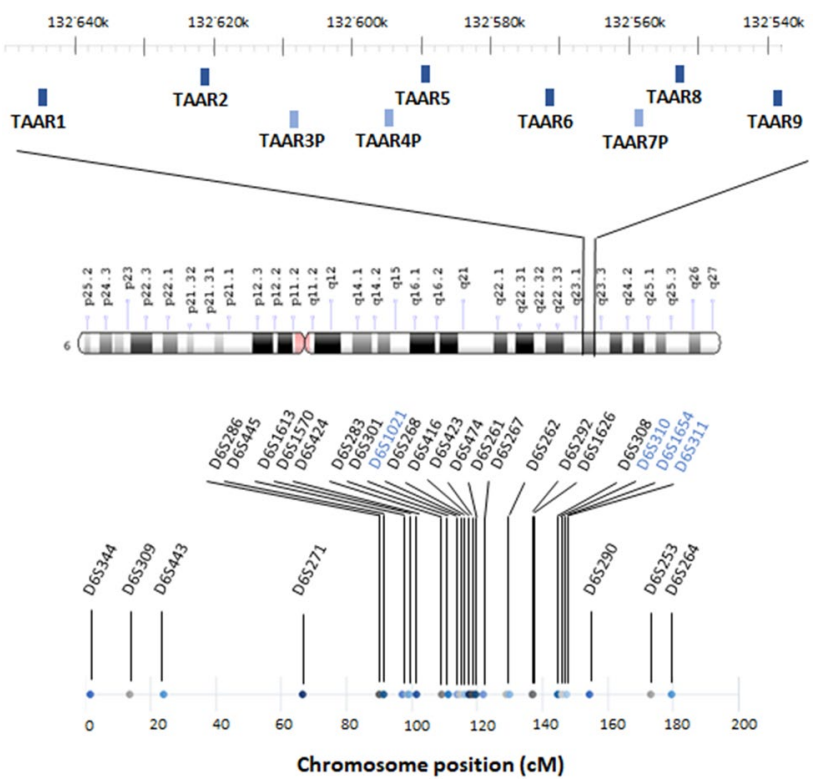

Fig. 1 Schematic representation of the human 108-kb genomic region in chromosome $6 \mathrm{q} 23$, containing the genes coding for trace amine-associated receptors (taars). The location of the genes refers to the most recent Genome Reference Consortium assembly (February 2019), i.e. GRCh38.p13. The human genome encompasses six taars (dark blue) all present as single-copy genes. TAAR3, TAAR4, and TAAR7 (light blue) underwent pseudogenization before humans diverged from gorillas. All members of the taar family generate short ( 1000-bp-long) intronless transcripts, with the exception of taar2, which contains two exons. This small genomic region has been repeatedly observed to be in genetic linkage with schizophrenia and bipolar disorder. Linkage studies pointed to a rather wide chromosomal region at $6 \mathrm{q}$ to contain one or more susceptibility loci for schizophrenia ( 102-180 cM from the pter). The polymorphic markers showing the higher peaks in linkage with schizophrenia (black) or bipolar disorder (blue) are depicted in the lower part of the figure

As mentioned above, most TAARs are chiefly expressed in the olfactory epithelium and it has been argued that they might play a crucial role in sensing important ethological signals, such as predator and prey odours, spoiled food, migratory cues, and pheromones, thereby activating appropriate behaviours (Ferrero et al. 2011). For instance, $\beta$-phenylethylamine, which is ligand for TAAR1 and TAAR4, is a carnivore odour from mountain lions, tigers and jaguars (Ferrero et al. 2011; Dewan et al. 2013). Taar gene dynamics might be affected by environmental and evolutionary factors. Indeed, taar duplications and positive selection might have helped therian mammals to adapt to ground-living and discriminate among a wide number of volatile amines. On the other hand, taars deteriorated as a consequence of relaxed selection in those primates who adapted to arboreality, therefore relying less on olfaction for survival (Eyun 2018).

Notably, TAAR1 is also stimulated, with $\mathrm{EC}_{50}$ in the nanomolar to micromolar range, by a wide array of 
psychoactive drugs, such as amphetamine, 3,4-methylenedioxymethamphetamine, known as "ecstasy" (Bunzow 2001; Miller et al. 2005; Simmler et al. 2016), D-lysergic acid diethylamide, bromocriptine, lisuride, nomifensine, apomorphine, ractopamin, clonidine, guanabenz, idozoxan, aminoindanes (2-aminoindane and 5-iodo-2-aminoindane), and m-chlorophenylpiperazine (Bunzow 2001; Hu et al. 2009; Liu et al. 2014; Sukhanov et al. 2014; Simmler et al. 2016).

On the whole, it has been speculated that TAARs could play an important role in the central nervous system function, and possibly contribute an etiological role to the pathogenesis of mental disorders. This review will cover the efforts made, under a genetic perspective, to unravel the association between TAARs and psychopathology. The small genomic region on chromosome 6 where taars are located has been repeatedly observed to be in genetic linkage with schizophrenia and bipolar disorder. Fine mapping association studies were subsequently integrated with genomewide association studies. Recent technological advances allowed large-scale sequencing of taars, as well as of the whole genomes of patients. Finally, the use of gene expression profiling and peptidome analyses has been used to identify TAAR dysregulation in specific diseases.

\section{Linkage Between Chromosome 6q23 and Mental Disorders}

In linkage analysis, no assumptions about specific genes are made. Polymorphic markers scattered over the genome at approximately equal distances, i.e. microsatellites with di- or tri-nucleotide repeats, are genotyped in family members, to determine whether they segregated with the disease (Bray and O'Donovan 2019). Markers are usually indicated by symbols such as DXS000, where D stands for DNA, $\mathrm{X}$ is a number that identifies chromosomal assignment, $\mathrm{S}$ denotes that it is a unique DNA sequence, and the final number is a specific identifier (Fig. 1). Chromosomal location may be expressed with cytogenetic notation, where chromosome number is followed by the letter " $p$ " (indicating the short arm) or "q" (indicating the long arm) and by a number that denotes microscope-identified bands and sub-bands. Distances between genes can be calculated on the basis of recombination frequencies, which are related to chromosomal crossover at meiosis and are expressed in centiMorgans $(\mathrm{cM})$, where $1 \mathrm{cM}$ corresponds to a frequency of $1 \%$ per generation. Distances can be also expressed as number of base-pairs calculated through sequencing, and in general in humans $1 \mathrm{cM}$ corresponds to about one million base-pairs (1 $\mathrm{Mbp}$ ). However, this is only an approximation, since recombination frequency is not the same in all regions.
The result of linkage analyses is expressed as logarithm of odds scores (LOD, i.e. logarithm to the base 10 of the likelihood of the observed data given linkage, divided by the likelihood of the data given no linkage), whose threshold for genome-wide significance is usually set at 3.3 (Lander and Kruglyak 1995). When dealing with complex traits, and/or constructing genetic maps, complex statistical methods are used, based on the so-called maximum likelihood estimates, and it is customary to use nonparametric linkage analyses (Risch 1990; Lander and Schork 1994).

Schizophrenia is a serious chronic mental disorder, with a prevalence of $\sim 1 \%$ worldwide. Its pathophysiology apparently involves a complex genetic component, which accounts for about $80 \%$ of the heritability and interacts with environmental factors (Kety et al. 1994). Evidence suggesting linkage of chromosome 6q23 to schizophrenia dates back to 1997, when Cao, et al. showed: (i) in a first dataset of affected sibling pairs in 53 nuclear families, excess allele sharing for markers on 6q13-q26, with a peak close to marker D6S416 in the interval 6q21-q22.3 ( $p=0.00024)$; (ii) in a replication dataset of 69 families from the NIMH Schizophrenia Genetics Initiative, maximum allele sharing at D6S424 $(p=0.0004), \mathrm{D} 6 \mathrm{~S} 283(p=0.0009)$ and close to D6S423 ( $p=0.0009)$ (Cao et al. 1997). These results were confirmed by a follow-up study, performed by the same group in a replication sample including 43 pedigrees (54 independent sibling pairs) of American and Australian origin (Martinez et al. 1999). Further support derived from a multicentre, collaborative study, where 734 pedigrees ( 824 independent sibling pairs) from 8 samples were scanned with 8 markers on chromosome 6q (Levinson et al. 2000). Such positive findings were all delimited to a relatively centromeric region spreading from $\sim 102$ to $120 \mathrm{cM}$ from the $\mathrm{p}$ terminal (pter). Another study reported significant linkage to schizophrenia in a more telomeric region at $6 \mathrm{q} 25$, with a peak at $\sim 180 \mathrm{cM}$, in an ample Swedish pedigree (Lindholm et al. 2001). Similar locations were reported in 5 Austrian families $(153.10 \mathrm{cM})$, and in 30 African-American pedigrees (138.11 cM) (Bailer et al. 2000; Kaufmann et al. 1998).

Besides the investigations focussing on specific chromosomal regions, a genome-wide survey of 71 families (86 independent sibling pairs, 462 markers) from Germany and Israel also found moderate to weak linkage signal in an area spanning an interval on 6q close to D6S271 $(\mathrm{LOD}=1.12)$ and D6S1613 (LOD = 1.11) (Schwab et al. 2000). More robust linkage was described in the investigation in 21 Arab-Israeli families multiplex affected with schizophrenia (155 individuals) from the catchment area of a Regional Mental Health Center, a highly ethnically homogeneous population with high birth rate, peculiarly high level of consanguinity and a low rate of intermarriage with other population groups in Israel (Jaber et al. 1994, 2000). Isolated populations offer the advantage to lower the genetic 
complexity and the heterogeneity of the environmental background, thereby improving the chance to find susceptibility loci (Peltonen et al. 2000). Lerer et al. detected the strongest evidence for linkage at chromosome 6q23 at marker D6S292 $(p=0.000004)$, located $136.97 \mathrm{cM}$ from the pter (Lerer et al. 2003). Taken altogether, these studies pointed to a rather wide chromosomal region at $6 \mathrm{q}$ to contain one or more susceptibility loci for schizophrenia $(\sim 102-180 \mathrm{cM}$ from the pter). Therefore, Levi, et al. refined their analyses on the Arab-Israeli population. Such approach allowed them to strengthen the evidence of linkage at D6S1626 $(136.97 \mathrm{cM})$, almost overlapping with the position reported in the previous genome scan, and to narrow the putative susceptibility region from 12.0 to $4.96 \mathrm{cM}$ (Levi et al. 2005).

Of note, in the investigations of the Arab-Israeli population, three diagnostic models were applied, ranging from a narrow to a broad definition of schizophrenia. The most robust evidence was obtained under the broad diagnostic model, which also included nonaffective psychoses (Lerer et al. 2003; Levi et al. 2005). Interestingly, the same region of chromosome $6 \mathrm{q}$ has emerged as harbouring susceptibility loci for bipolar disorder as well. Bipolar disorder is a severely disabling chronic disorder, with an estimated prevalence of approximately $4 \%$ worldwide (Merikangas et al. 2011). It is a complex highly heritable disorder, whose onset is determined by an interaction between liability and protective genes, with environmental factors impacting the expression of such polygenic information (Escamilla and Zavala 2008). Using a high-density genome-wide linkage analysis of 25 extended multiplex Portuguese families, Middleton, et al. identified a significant evidence for linkage to bipolar disorder on chromosome 6q22 at position 125.8 Mb (LOD =3.56) (Middleton et al. 2004). Similarly, the genome-wide scan of 153 pedigrees of bipolar families collected under the NIMH Genetics Initiative revealed a linkage at marker D6S311, located $147.5 \mathrm{cM}$ from the pter $(p=0.008)$ (McInnis et al. 2003). The analysis of 250 independent pedigrees from the same population, confirmed the positive findings, but at a different location, namely at $114 \mathrm{cM}$, close to the marker D6S1021 (Dick et al. 2003). The strategy of performing linkage analyses in population isolates proved useful also in the context of bipolar disorder. In nine multigenerational families from the northern Swedish geographically isolated population of Västerbotten, one locus at chromosome $6 \mathrm{q}$ emerged as linked to bipolar disorder, with a LOD of 3.2 under the recessive model. This locus was located $146 \mathrm{cM}$ from the pter in a candidate region between D6S310 and D6S1654 (Venken et al. 2005).

Notably, linkage studies are best suited for Mendelian disorders caused by one, or very few, genes, with a large impact on risk. Mental disorders generally adhere to complex patterns of inheritance, rather than to simple mono- or oligogenic models, consistently with the difficulty in identifying risk loci and a clear mode of transmission in most of the affected families (Bray and O'Donovan 2019). Notwithstanding this limitation, linkage studies have provided precious hints on taars as possible candidate genes for mental disorders. Their results have been summarized in Fig. 1.

\section{Association Between taars and Mental Disorders}

Linkage findings in chromosome 6q23 were followed by fine mapping association studies of taars (summarized in Table 1). Association studies are usually designed as case-control studies, in which a comparison is made of the frequency of genetic variants between affected and nonaffected individuals. Changes in single nucleotides are usually defined as single nucleotide polymorphisms (SNP) if they show population allele frequencies $>1 \%$, and single nucleotide variants (SNV) if their frequency is $<1 \%$. SNPs and SNVs are identified in the National Center for Biotechnology Information (NCBI) dbSNP database by an "rs" number, where "rs" stands for reference SNP cluster identification.

Significant case-control differences in allele or genotype distributions indicate either direct effects of the detected allele itself on liability to the condition, or linkage disequilibrium (LD) within the population between such detected (assayed) allele and the actual risk allele (Bray and O'Donovan 2019).

Most association studies have been focused on taar6, previously known as trace amine receptor 4 . Taar6 expression has been detected in the hippocampus, frontal cortex, amygdala and, at low levels, in the substantia nigra and basal ganglia (Borowsky 2001), all regions traditionally involved in the neurobiology of mental disorders (Grossberg 2000; Ivleva et al. 2017). Taar6 was reported to be associated with schizophrenia in an ethnical heterogenous sample of 192 families, previously linked to 6q23. In detail, the most significant associated SNP was rs4305745, located in taar6 $3^{\prime}$ untranslated region (3'-UTR), which could affect gene expression at the posttranscriptional level. This SNP exists in LD with two other rs6937506 and rs6903874, which, albeit associated, did not survive the Bonferroni correction for multiple testing (Duan et al. 2004). However, several studies failed to replicate these positive findings. As a matter of fact, no association between any of the assayed SNPs and schizophrenia was observed in Japanese (Ikeda et al. 2005) and European (Sanders et al. 2008) case-control samples, and families and parent-offspring triads of Arab-Israeli (Amann et al. 2006), Chinese Han (Duan et al. 2006), and European origin (Ludewick et al. 2008). Investigations aimed at detecting Taar6 SNPs associated to bipolar disorder similarly led to negative results (Abou Jamra et al. 2005; Venken et al. 2006). Nonetheless, a case-control study in a 
Table 1 Summary of the studies investigating molecular variants in human trace amine-associated receptors

\begin{tabular}{|c|c|c|c|c|c|}
\hline References & Gene & Study design & Disease/phenotype & Sample size & Population \\
\hline Duan et al. (2004) & TAAR6 & Association study & Schizophrenia & $\begin{array}{l}827 \text { subjects, from } 192 \\
\text { families }\end{array}$ & $\begin{array}{l}\text { European \& African } \\
\text { American }\end{array}$ \\
\hline \multirow[t]{2}{*}{$\begin{array}{l}\text { Abou Jamra et al. } \\
\text { (2005) }\end{array}$} & $\begin{array}{l}\text { TAAR1 } \\
\text { TAAR5 } \\
\text { TAAR6 }\end{array}$ & Association study & Bipolar disorder & $\begin{array}{l}118 \text { parent-offspring } \\
\text { triads }\end{array}$ & $\begin{array}{l}\text { European, German } \\
\text { descent }\end{array}$ \\
\hline & & & & $\begin{array}{l}263 \text { cases; } 430 \text { healthy } \\
\text { controls }\end{array}$ & \\
\hline Bly et al. (2005) & $T A A R 2$ & Gene sequencing & Schizophrenia & $\begin{array}{l}56 \text { cases; } 56 \text { healthy } \\
\text { controls }\end{array}$ & Caucasian \\
\hline \multirow[t]{2}{*}{ Ikeda et al. (2005) } & TAAR6 & Association study & Schizophrenia & $\begin{array}{l}405 \text { cases; } 401 \text { healthy } \\
\text { controls (first-set } \\
\text { analysis) }\end{array}$ & Japanese \\
\hline & & & & $\begin{array}{l}503 \text { cases; } 440 \text { healthy } \\
\text { controls (second-set } \\
\text { analysis) }\end{array}$ & \\
\hline Amann et al. (2006) & TAAR6 & Association study & Schizophrenia & $\begin{array}{l}85 \text { affected; } 34 \text { par- } \\
\text { ent-offspring triads; } \\
19 \text { families with } \geq 2 \\
\text { affected offspring }\end{array}$ & Arab-Israeli \\
\hline Duan et al. (2006) & TAAR6 & Association study & Schizophrenia & $\begin{array}{l}235 \text { parent-offspring } \\
\text { triads }\end{array}$ & Chinese Han \\
\hline Venken et al. (2006) & TAAR6 & Association study & Bipolar disorder & $\begin{array}{l}182 \text { cases; } 364 \text { healthy } \\
\text { controls; } 9 \text { families }\end{array}$ & Swedish $^{\mathrm{a}}$ \\
\hline Ludewick et al. (2008) & TAAR6 & Association study & Schizophrenia & $\begin{array}{l}79 \text { sib-pair families; } \\
125 \text { parent-offspring } \\
\text { triads }\end{array}$ & $\begin{array}{l}\text { European-German, } \\
\text { Hungarian-and } \\
\text { Israel }\end{array}$ \\
\hline Pae et al. (2008b) & TAAR6 & Association study & $\begin{array}{l}\text { Schizophrenia } \\
\text { Bipolar disorder } \\
\text { MDD }\end{array}$ & $\begin{array}{l}281 \text { schizophrenia; } 190 \\
\text { bipolar disorder; } \\
187 \text { MDD; } \\
288 \text { healthy controls }\end{array}$ & Korean \\
\hline Pae et al. (2008a) & TAAR6 & Association study & $\begin{array}{l}\text { Schizophrenia, PANSS } \\
\text { scores }\end{array}$ & 240 cases & Korean \\
\hline Sanders et al. (2008) & TAAR6 & Association study & $\begin{array}{l}\text { Schizophrenia and } \\
\text { schizoaffective } \\
\text { disorder }\end{array}$ & $\begin{array}{r}1870 \text { cases; } 2002 \\
\text { healthy controls }\end{array}$ & European \\
\hline Vladimirov et al. (2007) & $\begin{array}{l}\text { TAAR6 } \\
\text { TAAR2 } \\
\text { TAAR5 }\end{array}$ & Association study & Schizophrenia $^{\mathrm{b}}$ & $\begin{array}{l}1408 \text { subjects, from } \\
265 \text { families }\end{array}$ & Irish \\
\hline Pae et al. (2009b) & TAAR6 & $\begin{array}{l}\text { Association study, } \\
\text { epistasis with HSP-70 }\end{array}$ & Schizophrenia & $\begin{array}{l}281 \text { cases; } 288 \text { healthy } \\
\text { controls }\end{array}$ & Korean \\
\hline Pae et al. (2009a) & TAAR6 & $\begin{array}{l}\text { Association study, } \\
\text { epistasis with HSP-70 }\end{array}$ & $\begin{array}{l}\text { Bipolar disorder; } \\
\text { response to treatment }\end{array}$ & $\begin{array}{l}171 \text { cases; } 288 \text { healthy } \\
\text { controls }\end{array}$ & Korean \\
\hline Vladimirov et al. (2009) & TAAR6 & Association study & $\begin{array}{l}\text { Schizophrenia or poor- } \\
\text { outcome schizoaffec- } \\
\text { tive disorder }\end{array}$ & $\begin{array}{l}627 \text { cases; } 1021 \text { healthy } \\
\text { controls }\end{array}$ & Irish \\
\hline Pae et al. (2010) & TAAR6 & Association study & $\begin{array}{l}\text { Response to antide- } \\
\text { pressant treatment; } \\
\text { suicide }\end{array}$ & 187 cases & Korean \\
\hline Smith et al. (2012) & TAARI & Association study & Fibromyalgia & $\begin{array}{l}496 \text { cases; } 348 \text { healthy } \\
\text { controls }\end{array}$ & Caucasian \\
\hline Anttila et al. (2013) & TAAR6 TAAR7P & $\begin{array}{l}\text { Genome-wide meta- } \\
\text { analysis }\end{array}$ & Migraine & $\begin{array}{l}23285 \text { cases; } 95425 \\
\text { healthy controls ( } 29 \\
\text { GWAS }\end{array}$ & European \\
\hline Park et al. (2014) & TAAR6 & GWAS & $\begin{array}{l}\text { Change in } \% \Delta \mathrm{FEV} 1 \\
\text { following ICS treat- } \\
\text { ment }\end{array}$ & 189 cases & Korean \\
\hline
\end{tabular}


Table 1 (continued)

\begin{tabular}{|c|c|c|c|c|c|}
\hline References & Gene & Study design & Disease/phenotype & Sample size & Population \\
\hline Chang et al. (2015) & TAAR6 & Association study & $\begin{array}{l}\text { Change in } \% \Delta \mathrm{FEV} 1 \\
\text { following ICS treat- } \\
\text { ment }\end{array}$ & 246 cases & Korean \\
\hline John et al. (2017) & $T A A R 1$ & Exome sequencing & Schizophrenia & $\begin{array}{l}4 \text { members from } 1 \\
\text { family } \\
475+310 \text { cases; } 410 \\
\text { healthy controls }\end{array}$ & $\begin{array}{l}\text { North Indian (475) \& } \\
\text { American (310) }\end{array}$ \\
\hline Jones et al. (2017) & $\begin{array}{l}\text { TAAR1 } \\
\text { TAAR2 }\end{array}$ & GWAS & $\begin{array}{l}\text { Self-reported mosquito } \\
\text { bite size }\end{array}$ & 84724 subjects & European \\
\hline Mühlhaus et al. (2017) & TAARl & Gene sequencing & $\begin{array}{l}\text { Overweight/Obesity } \\
\text { and disturbed glucose } \\
\text { homeostasis }\end{array}$ & $\begin{array}{l}314 \text { cases; } 2018 \text { healthy } \\
\text { controls }^{c}\end{array}$ & German \\
\hline Shahin et al. (2018) & $T A A R 2$ & GWAS & Response to $\beta$-blockers & 699 subjects & Any \\
\hline Szekely et al. (2018) & $\begin{array}{l}\text { TAAR8 } \\
\text { TAAR6 }\end{array}$ & GWAS & Cerebellar growth & $\begin{array}{l}\text { LONG cohort: } 458 \\
\text { subjects (119 with } \\
\text { ADHD); } \\
\text { Generation R: } 257 \\
\text { subjects }\end{array}$ & Mixed $^{\mathrm{d}}$ \\
\hline
\end{tabular}

$\% \triangle F E V 1$ percentage of forced expiratory volume in $1 \mathrm{~s}$, GWAS genome-wide association study, HSP-70 heat shock protein 70, ICS inhaled corticosteroids, $M D D$ major depressive disorder

${ }^{\mathrm{a}}$ The sample originates from the genetically isolated region of Västerbotten in northern Sweden

${ }^{\mathrm{b}}$ Core schizophrenia, including schizophrenia, poor-outcome schizoaffective disorder and simple schizophrenia. No evidence of association for broader diagnostic categories: narrow psychosis spectrum, adding schizotypal personality disorder and all other nonaffective psychotic disorders; broad psychosis spectrum, adding mood-incongruent and mood-congruent psychotic affective illness, and paranoid, avoidant and schizoid personality disorders; very broad psychosis spectrum, including all psychosis spectrum disorders plus non-psychotic affective disorders, anxiety, alcoholism, etc

${ }^{\mathrm{c}}$ Diabetes-free subjects older than 60 years of age from the population-based Study of Health in Pomerania (SHIP and SHIP-TREND) cohorts

${ }^{\mathrm{d}}$ LONG cohort: 404 European Americans, 31 African Americans, 8 Asian Americans, 15 mixed ethnicity; Generation R: 177 White/Caucasian, 80 non-Caucasian (African, Asian, and Caribbean)

Korean population confirmed the association of the SNP rs6903874 in the 3'-UTR with schizophrenia, and, additionally, bipolar disorder (Pae et al. 2008b). The same authors demonstrated that taar6 SNPs might modulate the clinical presentation of disorders, in terms of symptom severity and response to treatment (Pae et al. 2008a, 2010).

Significant associations were also found in 265 pedigrees of the Irish Study of High-Density Schizophrenia Family between schizophrenia and the SNPs rs12189813 and rs9389011, and, more strongly, with two-four marker haplotypes including at least one of the former and/or SNP rs7772821. Notably, the strength of the association rose in subjects belonging to the core schizophrenia diagnostic groups and presenting with the most severe (top 20\%) delusions and hallucinations (Vladimirov et al. 2007). The SNP rs7772821 is located in the $3^{\prime}$-UTR and was shown by in silico analyses to affect the secondary structure of the mRNA, with implications for mRNA folding, conformation, and stability, and hence gene expression. Also, sequences incorrectly folded might be available for pairing with miRNA, which interfere with translation. Indeed, in silico tools predicted four target sequences for four miRNAs, hsamiR-92, hsa-miR-125a, hsa-miR-302b and hsa-miR-483, one of which (hsa-miR-125a) expressed in mouse brain (LagosQuintana et al. 2002). However, these findings could not be replicated in a case-control study performed by the same group in the same population (Vladimirov et al. 2009). Although this replication failure could be related to the different study design (multiplex families vs case-control), the possibility of false positive findings cannot be ruled out.

Apart from mental diseases, a few investigations evaluated the association between taar6 SNPs and respiratory function indices, particularly the change in the percentage of forced expiratory volume in $1 \mathrm{~s}$, following treatment with inhaled corticosteroids (see Table 1).

Table 1 also summarizes results related to the association of taar1, taar2 and taar5 SNPs with schizophrenia, bipolar disorder and fibromyalgia. In general, no significant relationship has been proven so far.

In conclusion, none of the reports of the association between taars and mental disorders has received sufficient universal replication, so their status remains uncertain. This lack of consistency can be explained by the small effects on susceptibility that are now known to typify common risk alleles, the low probability that any selected candidate allele is a true risk allele, and underpowered sample sizes (Bray 
and O'Donovan 2019). Quoting Vladimirov, et al. "If taar6 does contribute to liability for schizophrenia, this contribution is relatively small and may vary significantly between samples" (Vladimirov et al. 2009).

\section{Taar Detection in Genome-Wide Association Studies}

Over the last 12 years, technological advances in genotyping microarrays, together with the development of the HapMap project, made it possible to simultaneously genotype hundreds of thousands of SNPs in large samples. Such genome-wide association studies (GWAS) permitted to overcome the limitations of candidate gene approaches, such as: bias towards existing hypotheses, low probability of selecting a true risk allele from the millions present in the genome, low statistical power from small sample sizes. Therefore, they have now replaced the candidate/positional gene studies. Since common variants are related to small risk (odds ratios generally $<1.1$ ), very large sample sizes are required to detect them at a significance threshold that controls for multiple (up to 1 million) testing, generally set at $p<5 \times 10^{-8}$.

When interpreting GWAS, two main facts need to be taken into account: (1) most of the detected SNPs alter regulatory regions at a distance of several hundred kilobases from the gene of interest, rather than affecting the coding sequence; (2) linkage disequilibrium per se does not provide conclusive evidence about the causal role of a specific SNP $v s$ the causal role of correlated SNPs (Bray and O'Donovan 2019).

At the time of writing, five large GWAS detecting taar genes have been published, whose findings are summarized in Table 1. SNPs in genes of the taar superfamily have emerged from GWAS investigating genetic variants associated with: migraine (taar6, taar7p) (Anttila et al. 2013); change in forced expiratory volume following treatment with inhaled corticosteroids (taar6) (Park et al. 2014); self-reported mosquito bite size (taar1, taar2) (Jones et al. 2017); response to $\beta$-blockers (taar2) (Shahin et al. 2018); cerebellar growth (taar6, taar8) (Szekely et al. 2018). However, none of the detected variants reached the threshold for genome-wide significance.

\section{Copy Number Variants in taar Genes}

Copy number variants (CNVs) are deletions, duplications or insertions larger than $1 \mathrm{~kb}$ present in human genome in multiple sites. These regions of copy number changes may vary in size between $1 \mathrm{~kb}$ and megabases, and account for $1.2 \%$ variation in an individual human genome, relative to the reference genome. It has been calculated that an individual human genome contains an average of $70 \mathrm{CNV}$ s with a mean size of $341 \mathrm{~kb}$ (Redon et al. 2006). CNVs occur in the genome because of the presence of low copy repeats (LCRs), repetitive sequences of $10-500 \mathrm{~kb}$ with more than $90 \%$ sequence identity to another place in the genome. LCRs are substrates of non-allelic homologous recombination, leading to chromosomal rearrangement, namely deletion/insertion if the LCRs have the same orientation, and inversion, if LCRs are oppositely oriented (Rutkowski et al. 2017). CNVs are a major source of genome variability, which may be either benign or result in disease. Many factors play a role in determining the eventual impact of CNVs on human health, such as ethnical background, environment and other still unknown factors. At first, CNVs were identified with conventional karyotyping methods. Nowadays, much more sophisticated techniques are available, including array comparative genomic hybridization and, the most recent highthroughput next-generation sequencing. The clinical significance of CNVs must be interpreted carefully by geneticists, taking into account clinical information, such as parental inheritance, and considerations about $\mathrm{CNV}$ size (the smaller the size, the lower the risk of clinically relevant phenotypic consequences) and genomic content. Databases are available to guide CNV interpretation (Nowakowska 2017). Multiple studies have reported an enrichment of CNVs in neuropsychiatric disorders, including schizophrenia, autism spectrum disorders, intellectual disability, ADHD and Tourette syndrome, while CNVs seem to contribute less to disorders that are not commonly conceptualized as neurodevelopmental in origin, such as bipolar disorder and major depressive disorder (reviewed in (Rutkowski et al. 2017; Bray and O'Donovan 2019). Of note, such CNVs have some common features. First, beside neuropsychiatric disorders, they are associated with congenital craniofacial malformations. Second, they span large chromosomal regions, encompassing several genes with effects on several signalling pathways, cell types and tissues. Last, their contribution to risk is minimal, as compared to SNPs (Rutkowski et al. 2017). Similarly, CNVs have been described in association to metabolic disturbances as well, mainly diabetes (de Jesus Ascencio-Montiel et al. 2017). However, none of these analyses detected a significant association with the chromosomal region encompassing taar genes.

\section{Exome Sequencing and Changes in taar Gene Expression}

It is now established that complex disorders, e.g. mental and metabolic disorders, are characterized by highly polygenic architectures, which, beside common variants of weak effect, involve rarer variants that potentially have a much greater 
impact on risk, and many pleiotropic genes (Smoller et al. 2019). The available SNP genotyping arrays are not able to capture such rare, often de novo, DNA variants (defined as single nucleotide variants, SNVs, as discussed above). Nevertheless, in the last decade, the massive developments in sequencing technologies has made possible to screen also for SNVs, either at the level of a single target gene or of the socalled exome, i.e. the part ( $1 \%)$ of the genome that encodes proteins. Exonic mutations have the benefit to indicate specific genes, with predictable functional consequences, which makes them attractive for researchers seeking to generate cellular or animal models (Bray and O'Donovan 2019). An overall summary of the reported SNPs and SNVs in human taars is shown in Table 2.

Taarl has been the preferential target of these investigations, because of its potential role in the pathogenesis of mental and metabolic disorders, which has been extensively reviewed elsewhere (Rutigliano et al. 2017; Gainetdinov et al. 2018; Schwartz et al. 2018). In summary, TAAR1 is expressed across brain areas involved in emotions, reward and cognition, where it may represent a rheostat of monoaminergic and glutamatergic neurotransmission. TAAR1 has also been detected in stomach, neuroendocrine cells of the intestine, $\beta$ cells of the pancreas, and in brain areas involved in the control of energy metabolism. TAAR1 activation modifies nutrient-induced hormone secretion, and its potential role in diabetes and obesity is under investigation.

Striking evidence of the functional and behavioural consequences of spontaneous taarl mutations comes from genetic mouse models of voluntary methamphetamine (MA) drinking. By examining the progenitor strains of mouse lines selectively bred for high MA intake (MA drinking lines), it was found that the DBA/2 J strain bears a missense SNP in taarl at position 229, which could be traced as a spontaneous event at The Jackson Laboratory in 2001-2003. This SNP, which causes a proline to threonine amino acid change $\left(\right.$ Taar $\left.^{I m l J}\right)$, leads to TAAR1 loss of function. The homozygous Taar $^{l m l J}$ genotype is causally linked to increased MA consumption, reduced MA-induced conditioned taste aversion, and reduced MA-induced hypothermia (Reed et al. 2017).

In humans, a recent exome-sequencing study identified a heterozygous rare missense variant in taarl (rs367888752, C182F, Table 2) in the affected mother and two affected children but not in two unaffected siblings of a small schizophrenia family. This variant causes a cysteine to phenylalanine change in the second extracellular domain, thus breaking a highly conserved disulphide bond, which might tremendously impact on structure stability, cell surface localization, ligand binding and G-protein activation (Dohlman et al. 1990; Savarese et al. 1992; Perlman et al. 1995; Cook et al. 1996; Cook and Eidne 1997). Furthermore, the screening of taarl coding region yielded other seven rare variants (S47C,
F51L, Y294T, L295S, L253 =, A109T, V250A; details provided in Table 2) in 785 patients affected with sporadic schizophrenia and none of the 410 healthy controls. Based on their finding of a significant enrichment in the burden of taarl rare variants (MAF < 0.001$)$ among schizophrenia cases, the authors argued that taarl might be a strong schizophrenia risk-conferring gene (John et al. 2017). However, the potential functional impact of these rare variants was only assessed with in silico prediction tools.

Taarl has been screened for variants in a cohort of patients with impaired glycaemia and body weight regulation. Here, three heterozygous carriers of three rare missense variants were identified-R23C, S49L, and I171L (Table 2)-corresponding to a minor allele frequency (MAF) of $0.16 \%$, which is substantially higher than in nondiabetic controls aged $>60$ years in the general populationbased Study of Health in Pomerania (Muhlhaus et al. 2017). The carrier of R23C showed complete loss of insulin production, while the other two carriers were obese/overweight patients with a slight impairment of glucose homeostasis. Accordingly, the functional in vitro characterization of the three variants revealed a complete loss of function for $\mathrm{R} 23 \mathrm{C}$, versus partial impairment in receptor signalling for S49L, and no effect for I171L. Strikingly, the carriers of the function-disturbing variants presented mental health issues, namely a borderline intellectual functioning (R23C), and some not otherwise specified "psychiatric problems" (S49L). Both involved aminoacid residues, namely Arg23 and Ser49, are highly conserved among TAAR1 orthologues. $\operatorname{Arg} 23$ is located at the transition between the $\mathrm{N}$-terminal tail and the transmembrane helix 1 , where its side chain might interact with negatively charged residues of the extracellular loop 1 (Glu86 or Asp21). Ser49 points to the cytosol at the transition between the transmembrane helix 1 and the intracellular loop 1, and may contribute to the maintenance of the receptor structural conformation and to G-protein activation. Therefore, a role for taarl variants in the pathophysiology of insulin secretion, glucose homeostasis, and weight regulation could be speculated.

The functional consequences of the $\sim 50$ taarl variants reported in the dbSNP database still awaits clarification. In 2016, Shi et al. identified eight variants located in highly conserved motifs, to be characterized for agonist-induced function (C74Y, C182Y, K218I, T252A, C263G, C265 W, W291STOP, N300 K, R312S). Upon stimulation with $\beta$-phenylethylamine, no cAMP increase was observed in cells transfected with C74Y, T252A, and C265 W, while a sub-optimal cAMP response was observed for $\mathrm{C} 182 \mathrm{Y}$ and K218I (Shi et al. 2016).

Finally, a study with an underpowered sample size described a SNP of taar2, which replaces a tryptophan at position 123 with a stop codon. This SNP seems to be slightly more frequent in patients with schizophrenia, as 
Table 2 Single-nucleotide polymorphisms (SNPs) and variants (SNVs) in the human trace amine-associated receptor gene family

\begin{tabular}{|c|c|c|c|c|c|}
\hline DbSNP database ID & Gene & Location (AA change) & Disease/phenotype & Association & References \\
\hline \multirow[t]{12}{*}{ rs4305745 (G>A) } & TAAR6 & 3'-UTR & Schizophrenia & $p=0.0014$ & Duan et al. (2004) \\
\hline & & & & ns & Ikeda et al. (2005) \\
\hline & & & & ns & Duan et al. (2006) \\
\hline & & & & $\mathrm{ns}$ & Ludewick et al. (2008) \\
\hline & & & & ns & Vladimirov et al. (2007) \\
\hline & & & & ns & Vladimirov et al. (2009) \\
\hline & & & PANSS scores & ns & Pae et al. (2008a) \\
\hline & & & Response to antipsychotics & ns & Pae et al. (2009b) \\
\hline & & & $\mathrm{BD}$ & $\mathrm{ns}$ & Venken et al. (2006) \\
\hline & & & Schizophrenia; BD; MDD & ns & Pae et al. (2008b) \\
\hline & & & $\begin{array}{l}\text { Response to antidepres- } \\
\text { sants; suicide }\end{array}$ & ns & Pae et al. (2010) \\
\hline & & & $\mathrm{BD}$; response to treatment & ns & Pae et al. (2009a) \\
\hline \multirow[t]{11}{*}{$\operatorname{rs} 6937506(\mathrm{G}>\mathrm{A})$} & TAAR6 & 3'-UTR & Schizophrenia & $\begin{array}{l}p=0.0052, \text { d.n.s. } \\
\text { Bonferroni }\end{array}$ & Duan et al. (2004) \\
\hline & & & & ns & Ikeda et al. (2005) \\
\hline & & & & ns & Amann et al. (2006) \\
\hline & & & & ns & Duan et al. (2006) \\
\hline & & & & ns & Ludewick et al. (2008) \\
\hline & & & & ns & Vladimirov et al. (2007) \\
\hline & & & $\mathrm{BD}$ & ns & Venken et al. (2006) \\
\hline & & & Schizophrenia; BD; MDD & ns & Pae et al. (2008b) \\
\hline & & & Suicide & $p=0.002$ & Pae et al. (2010) \\
\hline & & & Response to antipsychotics & $\begin{array}{l}p<0.001 ; \text { balance } \\
\quad \text { accuracy }=0.53 \\
\quad(\text { weak) }\end{array}$ & Pae et al. (2009b) \\
\hline & & & $\mathrm{BD}$; response to treatment & ns & Pae et al. (2009a) \\
\hline \multirow[t]{15}{*}{ rs6903874 (T>C) } & TAAR6 & 3'-UTR & Schizophrenia & $\begin{array}{c}p=0.0026, \text { d.n.s. } \\
\text { Bonferroni }\end{array}$ & Duan et al. (2004) \\
\hline & & & & ns & Ikeda et al. (2005) \\
\hline & & & & ns & Amann et al. (2006) \\
\hline & & & & ns & Duan et al. (2006) \\
\hline & & & & ns & Ludewick et al. (2008) \\
\hline & & & & $p=0.012$ & Pae et al. (2008b) \\
\hline & & & & ns & Vladimirov et al. (2007) \\
\hline & & & & ns & Vladimirov et al. (2009) \\
\hline & & & PANSS scores & ns & Pae et al. (2008a) \\
\hline & & & $\mathrm{BD}$ & ns & Venken et al. (2006) \\
\hline & & & & $p=0.005$ & Pae et al. (2008b) \\
\hline & & & $\begin{array}{l}\text { MDD, response to antide- } \\
\text { pressants }\end{array}$ & $p=0.006$ & Pae et al. (2010) \\
\hline & & & $\begin{array}{l}\text { Change in } \% \Delta \mathrm{FEV} 1 \text { fol- } \\
\text { lowing ICS }\end{array}$ & $\mathrm{ns}$ & Chang et al. (2015) \\
\hline & & & Response to antipsychotics & $\begin{array}{l}p<0.001 ; \text { balance } \\
\quad \text { accuracy }=0.52-0.54 \\
\quad(\text { weak })\end{array}$ & Pae et al. (2009b) \\
\hline & & & $\mathrm{BD}$; response to treatment & ns & Pae et al. (2009a) \\
\hline \multirow[t]{2}{*}{ rs2840837 (A>G) } & TAAR6 & Intergenic & Schizophrenia & ns & Duan et al. (2004) \\
\hline & & & & $\mathrm{ns}$ & Amann et al. (2006) \\
\hline
\end{tabular}


Table 2 (continued)

\begin{tabular}{|c|c|c|c|c|c|}
\hline DbSNP database ID & Gene & Location (AA change) & Disease/phenotype & Association & References \\
\hline \multirow[t]{3}{*}{$\operatorname{rs} 1361280(A>G)$} & TAAR6 & Intergenic & Schizophrenia & ns & Duan et al. (2004) \\
\hline & & & & ns & Amann et al. (2006) \\
\hline & & & & ns & Vladimirov et al. (2007) \\
\hline \multirow[t]{3}{*}{ rs4473885 $(\mathrm{C}>\mathrm{T})$} & TAAR6 & 5'-UTR & Schizophrenia & ns & Duan et al. (2004) \\
\hline & & & & ns & Ikeda et al. (2005) \\
\hline & & & & ns & Amann et al. (2006) \\
\hline \multirow[t]{3}{*}{ rs4085406 $(\mathrm{A}>\mathrm{G})$} & TAAR6 & 5'-UTR & Schizophrenia & ns & Duan et al. (2004) \\
\hline & & & & ns & Ikeda et al. (2005) \\
\hline & & & & ns & Amann et al. (2006) \\
\hline \multirow[t]{4}{*}{ rs6907909 $(A>G)$} & TAAR6 & 5'-UTR & Schizophrenia & ns & Duan et al. (2004) \\
\hline & & & & $\begin{array}{l}p=0.0354 \text { (first-set } \\
\quad \text { analysis) } \\
\mathrm{ns}(\text { second-set analy- } \\
\quad \text { sis) }\end{array}$ & Ikeda et al. (2005) \\
\hline & & & & ns & Amann et al. (2006) \\
\hline & & & & $\mathrm{ns}$ & Ludewick et al. (2008) \\
\hline \multirow[t]{6}{*}{ rs8192624 (G>A) } & TAAR6 & Exon, missense & Schizophrenia & ns & Duan et al. (2004) \\
\hline & & & & $\begin{array}{l}p=0.014 \text { (family } \\
\text { study) } \\
p=0.024(\text { case }- \\
\text { control) }\end{array}$ & $\begin{array}{l}\text { Abou Jamra et al. } \\
\text { (2005) }\end{array}$ \\
\hline & & & & $\mathrm{ns}$ & Amann et al. (2006) \\
\hline & & & & $\mathrm{ns}$ & Vladimirov et al. (2007) \\
\hline & & & & $\mathrm{ns}$ & Vladimirov et al. (2009) \\
\hline & & & $\begin{array}{l}\text { Change in } \% \Delta \text { FEV1 fol- } \\
\text { lowing ICS }\end{array}$ & ns & Chang et al. (2015) \\
\hline \multirow[t]{15}{*}{ rs8192625 (G>A) } & TAAR6 & Exon, missense & Schizophrenia & $\mathrm{ns}$ & Duan et al. (2004) \\
\hline & & & & ns & Ikeda et al. (2005) \\
\hline & & & & ns & Amann et al. (2006) \\
\hline & & & & ns & Ludewick et al. (2008) \\
\hline & & & & ns & Sanders et al. (2008) \\
\hline & & & & ns & Vladimirov et al. (2007) \\
\hline & & & & ns & Vladimirov et al. (2009) \\
\hline & & & PANSS scores & $\begin{array}{l}p=0.04 \text { (total score) } \\
p=0.01 \text { (positive } \\
\text { score) } \\
p=0.007 \text { (difference } \\
\text { from baseline) }\end{array}$ & Pae et al. (2008a) \\
\hline & & & Response to antipsychotics & ns & Pae et al. (2009b) \\
\hline & & & $\mathrm{BD}$ & ns & $\begin{array}{l}\text { Abou Jamra et al. } \\
\text { (2005) }\end{array}$ \\
\hline & & & & ns & Venken et al. (2006) \\
\hline & & & $\mathrm{BD}$; response to treatment & ns & Pae et al. (2009a) \\
\hline & & & Schizophrenia; BD; MDD & ns & Pae et al. (2008b) \\
\hline & & & $\begin{array}{l}\text { Response to antidepres- } \\
\text { sants; suicide }\end{array}$ & ns & Pae et al. (2010) \\
\hline & & & $\begin{array}{l}\text { Change in } \% \Delta \mathrm{FEV} 1 \text { fol- } \\
\text { lowing ICS }\end{array}$ & ns & Chang et al. (2015) \\
\hline
\end{tabular}


Table 2 (continued)

\begin{tabular}{|c|c|c|c|c|c|}
\hline DbSNP database ID & Gene & Location (AA change) & Disease/phenotype & Association & References \\
\hline \multirow[t]{8}{*}{ rs7772821 (T>G) } & TAAR6 & 3'-UTR & Schizophrenia & ns & Duan et al. (2004) \\
\hline & & & & ns & Ikeda et al. (2005) \\
\hline & & & & ns & Amann et al. (2006) \\
\hline & & & & ns & Vladimirov et al. (2007) \\
\hline & & & & ns & Vladimirov et al. (2009) \\
\hline & & & $\mathrm{BD}$ & ns & $\begin{array}{l}\text { Abou Jamra et al. } \\
\text { (2005) }\end{array}$ \\
\hline & & & $\begin{array}{l}\text { Change in } \% \Delta \text { FEV } 1 \text { fol- } \\
\text { lowing ICS }\end{array}$ & $p=6.08 \times 10^{-5}, \mathrm{~ns}$ & Park et al. (2014) \\
\hline & & & $\begin{array}{l}\text { Change in } \% \Delta \text { FEV1 fol- } \\
\text { lowing ICS }\end{array}$ & $\begin{array}{l}p_{\text {corr }}=0.002(\text { codomi }- \\
\text { nant model }) \\
p_{\text {corr }}=0.03 \text { (dominant } \\
\text { model) } \\
p_{\text {corr }}=0.01 \text { (recessive } \\
\text { model) }\end{array}$ & Chang et al. (2015) \\
\hline \multirow[t]{2}{*}{ rs7745308 (T>G) } & TAAR6 & 3'-UTR & Schizophrenia & ns & Duan et al. (2004) \\
\hline & & & & ns & Amann et al. (2006) \\
\hline \multirow[t]{3}{*}{ rs6912930 $(\mathrm{T}>\mathrm{G})$} & TAAR6 & 3'-UTR & Schizophrenia & ns & Duan et al. (2004) \\
\hline & & & & ns & Amann et al. (2006) \\
\hline & & & $\begin{array}{l}\text { Change in } \% \Delta \text { FEV1 fol- } \\
\text { lowing ICS }\end{array}$ & ns & Chang et al. (2015) \\
\hline \multirow[t]{4}{*}{ rs7765655 $(\mathrm{G}>\mathrm{A})$} & TAAR6 & Intergenic & Schizophrenia & ns & Duan et al. (2004) \\
\hline & & & & ns & Amann et al. (2006) \\
\hline & & & & ns & Vladimirov et al. (2007) \\
\hline & & & & ns & Vladimirov et al. (2009) \\
\hline \multirow[t]{2}{*}{ rs4129284 (C>T) } & TAAR6 & Intergenic & Schizophrenia & ns & Duan et al. (2004) \\
\hline & & & & ns & Amann et al. (2006) \\
\hline \multirow[t]{2}{*}{ rs9321354 (A>C) } & TAAR6 & 3'-UTR & Schizophrenia & ns & Duan et al. (2004) \\
\hline & & & & ns & Amann et al. (2006) \\
\hline \multirow[t]{2}{*}{ rs9373026 (C>G) } & TAAR6 & 5'-UTR & Schizophrenia & ns & Ikeda et al. (2005) \\
\hline & & & $\begin{array}{l}\text { Change in } \% \Delta \text { FEV1 fol- } \\
\text { lowing ICS }\end{array}$ & ns & Chang et al. (2015) \\
\hline \multirow[t]{7}{*}{$\operatorname{rs} 7452939(\mathrm{G}>\mathrm{A})^{\mathrm{a}}$} & TAAR6 & 3'-UTR & Schizophrenia & ns & Ikeda et al. (2005) \\
\hline & & & & $\begin{array}{l}p=0.019, \text { d.n.s. Bon- } \\
\text { ferroni }\end{array}$ & Pae et al. (2008b) \\
\hline & & & & $\begin{array}{l}p<0.001 ; \text { balance } \\
\text { accuracy }=0.57 \\
\quad(\text { weak })\end{array}$ & Pae et al. (2009b) \\
\hline & & & PANSS scores & ns & Pae et al. (2008a) \\
\hline & & & $\mathrm{BD}$; response to treatment & ns & Pae et al. (2009a) \\
\hline & & & $\begin{array}{l}\text { Response to antidepres- } \\
\text { sants; suicide }\end{array}$ & ns & Pae et al. (2010) \\
\hline & & & $\begin{array}{l}\text { Change in } \% \Delta \text { FEV1 fol- } \\
\text { lowing ICS }\end{array}$ & ns & Chang et al. (2015) \\
\hline \multirow[t]{2}{*}{ rs12189813 (G>C) } & TAAR6 & Intergenic & Schizophrenia & $p=0.02$ & Vladimirov et al. (2007) \\
\hline & & & & ns & Vladimirov et al. (2009) \\
\hline \multirow[t]{2}{*}{ rs9389011 (T>C) } & TAAR6 & Intergenic & Schizophrenia & $p=0.03$ & Vladimirov et al. (2007) \\
\hline & & & & ns & Vladimirov et al. (2009) \\
\hline rs8192622 (C>T) & TAAR6 & & Schizophrenia & ns & Vladimirov et al.(2009) \\
\hline rs3813354 (G>A) & & & & ns & Vladimirov et al. (2007) \\
\hline
\end{tabular}


Table 2 (continued)

\begin{tabular}{|c|c|c|c|c|c|}
\hline DbSNP database ID & Gene & Location (AA change) & Disease/phenotype & Association & References \\
\hline rs9389015 (C>T) & & & & ns & \\
\hline \multirow[t]{2}{*}{ rs9389020 (T>C) } & TAAR6 & & Schizophrenia & ns & Vladimirov et al. (2007) \\
\hline & & & & $p=0.0228$ & Vladimirov et al. (2009) \\
\hline \multirow[t]{2}{*}{ rs9493381 $(\mathrm{G}>\mathrm{T})$} & TAAR6 & 5'-UTR & $\begin{array}{l}\text { Change in } \% \Delta \text { FEV1 fol- } \\
\text { lowing ICS }\end{array}$ & ns & Chang et al. (2015) \\
\hline & & & Cerebellar growth & $p=1.27 \times 10^{-6}, \mathrm{~ns}$ & Szekely et al. (2018) \\
\hline \multirow[t]{2}{*}{ rs8192618 (G>A) } & TAAR1 & $\begin{array}{l}\text { Exon, missense } \\
\text { R23C) }\end{array}$ & Schizophrenia & $\begin{array}{l}\text { NI_cases: } 450 / 0 / 0^{b} \\
\text { US—cases: } 296 / 4 / 0 \\
\text { controls: } 401 / 0 / 0\end{array}$ & John et al. (2017) \\
\hline & & & $\begin{array}{l}\text { Overweight/Obesity and } \\
\text { disturbed glucose homeo- } \\
\text { stasis }\end{array}$ & $\begin{array}{l}\text { cases: } 313 / 1 / 0^{\mathrm{b}} \\
\text { controls: } 2018 / 0 / 0\end{array}$ & Muhlhaus et al. (2017) \\
\hline \multirow[t]{2}{*}{ rs8192620 $(\mathrm{T}>\mathrm{C})$} & TAARl & Exon, synon (V288=) & $\mathrm{BD}$ & $\mathrm{ns}$ & $\begin{array}{l}\text { Abou Jamra et al. } \\
\text { (2005) }\end{array}$ \\
\hline & & & Schizophrenia & $\begin{array}{l}\text { NI_cases: } \\
\text { 277/162/21 } \\
\text { US-cases: } 170 / 75 / 9 \\
\text { controls: } 230 / 139 / 31\end{array}$ & John et al. (2017) \\
\hline \multirow[t]{2}{*}{ rs8192619 (G>A) } & $T A A R 1$ & Exon, synon (C265=) & Fibromyalgia & $p=1.11 \times 10^{-5}$ & Smith et al. (2012) \\
\hline & & & Schizophrenia & $\begin{array}{l}\text { NI_cases: } 394 / 66 / 0^{b} \\
\text { US_cases: } 228 / 28 / 1 \\
\text { controls: } 336 / 63 / 1\end{array}$ & John et al. (2017) \\
\hline ss28447860 (C>G) & TAAR6 & Intergenic & Schizophrenia & ns & Duan et al. ((2004) \\
\hline ss28447862 (T>C) & & & & ns & \\
\hline $\operatorname{ss} 28447876(\mathrm{G}>\mathrm{A})$ & & & & ns & \\
\hline $\begin{array}{l}\operatorname{ss} 28447863(A>G) \\
\operatorname{ss} 28447865(C>T)\end{array}$ & & & & ns & \\
\hline $\operatorname{ss} 28447866(\mathrm{G}>\mathrm{A})$ & & & & $\mathrm{ns}$ & \\
\hline $\operatorname{ss} 28447871(\mathrm{G}>\mathrm{A})$ & & & & $\mathrm{ns}$ & \\
\hline rs8192627 (A>C) & TAAR5 & Exon, missense & $\mathrm{BD}$ & ns & $\begin{array}{l}\text { Abou Jamra et al. } \\
\text { (2005) }\end{array}$ \\
\hline Not reported & TAAR2 & $\begin{array}{r}\text { Exon, missense } \\
(\mathrm{W} 123 \mathrm{STOP})\end{array}$ & Schizophrenia & $\mathrm{ns}$ & Bly (2005) \\
\hline rs17078770 (-/A) & TAAR6 & 3'-UTR & Schizophrenia & $\mathrm{ns}$ & Ikeda et al. (2005) \\
\hline rs2842899 (T>A) & TAAR6 & Intergenic & Schizophrenia & ns & Vladimirov et al. (2007) \\
\hline rs2153174 $(\mathrm{G}>\mathrm{T})$ & & & & ns & \\
\hline rs1933988 (A>C) & & & & ns & \\
\hline rs2255071 $(\mathrm{C}>\mathrm{T})$ & & & & $\mathrm{ns}$ & \\
\hline rs7744878 $(\mathrm{G}>\mathrm{A})$ & & & & $\mathrm{ns}$ & \\
\hline rs7759367 (G>A) & & & & ns & \\
\hline rs17195227 (T>C) & & & & ns & \\
\hline rs17061477 (A>C) & & & & $\mathrm{ns}$ & \\
\hline rs4320395 (G>A) & & & & $\mathrm{ns}$ & \\
\hline rs9402439 (C>G) & & & & $\mathrm{ns}$ & \\
\hline Not shown & $T A A R 2$ & Not shown & Schizophrenia & ns & Vladimirov et al. (2007) \\
\hline Not shown & TAAR5 & Not shown & Schizophrenia & ns & Vladimirov et al. (2007) \\
\hline rs9399032 (T>A) & $\begin{array}{l}\text { TAAR6; } \\
\text { TAAR7P }\end{array}$ & Intergenic & Migraine & $p=3.66 \times 10^{-6}, \mathrm{~ns}$ & Anttila et al. (2013) \\
\hline rs11961899 (A>G) & TAAR6 & 5'-UTR & $\begin{array}{l}\text { Change in } \% \Delta \mathrm{FEV} 1 \text { fol- } \\
\text { lowing ICS }\end{array}$ & ns & Chang et al. (2015) \\
\hline rs9402427 (C>T) & & 5'-UTR & & ns & \\
\hline rs9402428 (G>A) & & 5'-UTR & & ns & \\
\hline rs9373024 (T>C) & & 5'-UTR & & ns & \\
\hline
\end{tabular}


Table 2 (continued)

\begin{tabular}{|c|c|c|c|c|c|}
\hline DbSNP database ID & Gene & Location (AA change) & Disease/phenotype & Association & References \\
\hline rs9389007 (A>G) & & 5'-UTR & & ns & \\
\hline rs11154685 (A>G) & & 3'-UTR & & ns & \\
\hline rs17802869 $(\mathrm{T}>\mathrm{G})$ & & 3'-UTR & & ns & \\
\hline rs367888752 (C>A) & $T A A R 1$ & Exon, missense $(\mathrm{C} 182 \mathrm{~F})$ & Schizophrenia & $\begin{array}{l}\text { Only present in } \\
\text { affected individuals }\end{array}$ & John et al. (2017) \\
\hline rs $149785438(\mathrm{G}>\mathrm{C})$ & & Exon, missense (S47C) & & & \\
\hline rs567495315 (G>T) & & Exon, missense (F51L) & & & \\
\hline $\begin{array}{l}\text { Chr6: } 132966261 \\
(\mathrm{G}>\mathrm{C})^{\mathrm{c}}\end{array}$ & & Exon, missense (Y294T) & & & \\
\hline $\begin{array}{l}\text { Chr6: } 132966259 \\
(A>G)^{c}\end{array}$ & & Exon, missense (L295S) & & & \\
\hline rs $182618382(A>G)$ & & Exon, synon (L253=) & & & \\
\hline $\begin{array}{l}\text { Chr6: } 132966818 \\
(\mathrm{C}>\mathrm{T})^{\mathrm{c}}\end{array}$ & & Exon, missense (A109T) & & & \\
\hline $\begin{array}{l}\text { Chr6: } 132966394 \\
\quad(A>G)^{c}\end{array}$ & & Exon, missense (V250A) & & & \\
\hline rs558642256 (T>A) & & Exon, missense (S28C) & & & \\
\hline $\operatorname{rs} 73775159(\mathrm{~T}>\mathrm{G})$ & & Exon, synon $(\mathrm{T} 37=)$ & & & \\
\hline rs $377606507(\mathrm{C}>\mathrm{T})$ & & Exon, synon $(E 86=)$ & & & \\
\hline rs77004036 $(\mathrm{G}>\mathrm{A})$ & & Exon, synon $(\mathrm{T} 102=)$ & & & \\
\hline $\operatorname{rs} 73557824(A>G)$ & & Exon, missense $(\mathrm{Y} 173 \mathrm{H})$ & & & \\
\hline rs114701711 $(\mathrm{A}>\mathrm{G})$ & & Exon, synon (L215=) & & & \\
\hline rs540278394 (C>T) & & Exon, missense (S244 N) & & & \\
\hline rs6926857 (T>C) & & Exon, missense (T252A) & & & \\
\hline rs8192621 (T>C) & & Exon, missense (R312R) & & & \\
\hline rs $184898731(\mathrm{G}>\mathrm{A})$ & $\begin{array}{l}\text { TAAR1; } \\
\text { TAAR2 }\end{array}$ & Intergenic & $\begin{array}{l}\text { Self-reported mosquito } \\
\text { bite size }\end{array}$ & $p=8.64 \times 10^{-6}, \mathrm{~ns}$ & Jones et al. (2017) \\
\hline $\begin{array}{l}\text { rs } 140960896(\mathrm{G}>\mathrm{A}) \\
\mathrm{rs} 200795344(\mathrm{~T}>\mathrm{A})\end{array}$ & TAAR1 & $\begin{array}{l}\text { Exon, missense (S49L) } \\
\text { Exon, missense (I171L) }\end{array}$ & $\begin{array}{l}\text { Overweight/Obesity and } \\
\text { disturbed glucose homeo- } \\
\text { stasis }\end{array}$ & $\begin{array}{l}\text { Cases: } 313 / 1 / 0^{\mathrm{b} ;} \text { con- } \\
\text { trols: } 2000 / 9 / 0^{\mathrm{b}} \\
\text { Cases: } 313 / 1 / 0^{\mathrm{b} ;} \text { con- } \\
\text { trols: not available }\end{array}$ & Muhlhaus et al. (2017) \\
\hline rs9385619 $(\mathrm{C}>\mathrm{T})$ & TAAR2 & 5'-UTR & Response to $\beta$-blockers & $p=8.23 \times 10^{-6}, \mathrm{~ns}$ & Shahin et al. (2018) \\
\hline
\end{tabular}

$\% \triangle F E V 1$ percentage of forced expiratory volume in $1 \mathrm{~s}, B D$ bipolar disorder, d.n.s. did not survive, ICS inhaled corticosteroids, $M D D$ major depressive disorder, NI North Indian, PANSS positive and negative syndrome scale, US American, UTR untranslated region

${ }^{a}$ rs7452939 has merged into rs4305746

${ }^{\mathrm{b}} \mathrm{WT} /$ Hetero/variant homozygous genotypes

${ }^{c}$ Reference SNP cluster ID not available; reported as position in assembly GRCh37.p13

compared to healthy controls, although statistical significance was borderline. Moreover, there is still no evidence of taar2 expression in the brain, so the relevance of this finding is uncertain (Bly 2005).

It is possible that carriers of sub-functional receptors might benefit from treatments with TAAR1 agonists. The current status of the development of TAAR 1 agonists as therapeutic agents for mental and metabolic disorders has been recently summarized in (Berry et al. 2017). Briefly, preclinical evidence indicates that TAAR1 agonists might be useful for the treatment of schizophrenia. Indeed, TAAR1 agonists appear to offer some interesting advantages as compared to commonly used antipsychotics. Beside controlling hyper-dopaminergia, classically considered the neurochemical underpinning of positive symptoms of schizophrenia, they act on hypo-glutamatergia, possibly related to negative and cognitive schizophrenia symptoms. Also, they do so while limiting common side effects of antipsychotics, such as extra-pyramidal side effects and olanzapine-induced weight gain. As such, a mixed 5HT1A/TAAR1 agonist, SEP-363856 (Sunovion Pharmaceuticals), is under phase I clinical trial for schizophrenia, with promising results. Interestingly, SEP-363856 compound was shown to modulate the dopamine reward 
pathway, according to the preclinical observation of anticraving effects of TAAR1 agonists for drugs that activate the dopaminergic reward pathway. As regards metabolic disturbances, clinical testing has not begun as yet, although TAAR1 agonists demonstrated, in relevant animal models, to induce weight loss, improve insulin sensitivity, reduce plasma and hepatic triglycerides.

Because of the variability in penetrance, genome sequencing should be associated to profiling gene expression and peptide regulation. The term gene-expression profiling refers to the simultaneous assessment of the relative transcript abundance of a large number of genes, in multiple experiments comparing different conditions. According to the scope, mRNA levels are assayed with microarrays or next-generation sequencing technologies (RNA-seq). Similarly, the peptidome assessment refers to the investigation of the array of endogenous peptides present in the intracellular and extracellular space of the body in a system-wide manner and holds the promise to facilitate the identification of biomarkers.

Using gene expression profiling, differential expression of 721 genes was demonstrated in the hippocampus in an animal model of autism, consisting of valproic acid-treated rats. In particular, taar $h$ and taar $7 b$ emerged as hub genes in the significantly downregulated neuroactive ligand-receptor interaction pathway. These findings suggest that TAARs might play an important role in autism spectrum disorders (Huang et al. 2016). Accordingly, the peptidome analysis of 68 Han Chinese children with autism and 80 healthy controls allowed the identification of 8 potential serum biomarker peaks, including TAAR6 (Yang et al. 2018). A significantly different peak area of the TAAR6 fragment was also reported in 30 patients with vascular cognitive impairment, relative to 30 healthy controls (Xi et al. 2009).

However, the direction of the differences was opposite, in that TAAR6 levels were elevated in autism spectrum disorders, and reduced in vascular cognitive impairment. Therefore, these results should be interpreted with great caution, and validated in independent samples.

\section{Conclusions}

On the basis of the expression, pharmacology, and putative functional role of TAARs, it was hypothesized that subjects carrying mutant receptors might be predisposed to several diseases, particularly mental and metabolic disorders. Following the evidence of a linkage between chromosome $6 \mathrm{q} 23$ and schizophrenia or affective disorders, several teams have attempted to find susceptibility loci for mental disorders in taars, especially taar6, with inconclusive results. Similarly, susceptibility loci identified close to taars by GWAS did not reach genome-wide significance. However, rare variants have been detected in taars, particularly in taarl, by sequencing screening in cohorts of patients with mental and metabolic disorders. Such rare variants were demonstrated in vitro to disrupt the function of the receptor. It is possible that carriers of these nonfunctional variants could be at higher risk for mental and metabolic disorders, and individuals carrying sub-functional receptors might benefit from treatments with TAAR1 agonists. Finally, results of transcriptomic and peptidomic analyses, although very preliminary, suggest that TAARs, in particular TAAR6, might be involved in the pathophysiology of autism spectrum disorders and vascular cognitive impairment. In conclusion, some members of the human TAAR superfamily could represent promising targets for the treatment of mental and/or metabolic disorders, but further investigation is needed to reach definite conclusions.

Author Contributions Both authors decided upon the general outline of the review. GR wrote the first draft of the manuscript and prepared the figure. RZ revised and integrated the text and the tables.

Funding This work was partly supported by the University of Pisa (PRA 2018 to RZ).

\section{Compliance with Ethical Standards}

Conflict of interest The authors declare that they have no conflicts of interest.

Open Access This article is distributed under the terms of the Creative Commons Attribution 4.0 International License (http://creativeco mmons.org/licenses/by/4.0/), which permits unrestricted use, distribution, and reproduction in any medium, provided you give appropriate credit to the original author(s) and the source, provide a link to the Creative Commons license, and indicate if changes were made.

\section{References}

Abou Jamra R et al (2005) A family-based and case-control association study of trace amine receptor genes on chromosome 6 q23 in bipolar affective disorder. Mol Psychiatry 10:618-620. https://doi. org/10.1038/sj.mp.4001665

Amann D et al (2006) The trace amine receptor 4 gene is not associated with schizophrenia in a sample linked to chromosome 6q23. Mol Psychiatry 11:119-121. https://doi.org/10.1038/sj.mp.4001752

Anttila V et al (2013) Genome-wide meta-analysis identifies new susceptibility loci for migraine. Nat Genet 45:912-917. https://doi. org/10.1038/ng.2676

Bailer U et al (2000) Genome scan for susceptibility loci for schizophrenia. Neuropsychobiology 42:175-182. https://doi. org/10.1159/000026690

Berry MD (2004) Mammalian central nervous system trace amines Pharmacologic amphetamines, physiologic neuromodulators. J Neurochem 90:257-271. https://doi.org/10.111 1/j.1471-4159.2004.02501.x

Berry MD, Gainetdinov RR, Hoener MC, Shahid M (2017) Pharmacology of human trace amine-associated receptors: therapeutic 
opportunities and challenges. Pharmacol Ther. https://doi. org/10.1016/j.pharmthera.2017.07.002

Bly M (2005) Examination of the trace amine-associated receptor 2 (TAAR2). Schizophr Res 80:367-368. https://doi.org/10.1016/j. schres.2005.06.003

Borowsky B (2001) Trace amines: identification of a family of mammalian G protein-coupled receptors. Proc Natl Acad Sci USA. https://doi.org/10.1073/pnas.151105198

Boulton AA (1974) Letter: amines and theories in psychiatry. Lancet 2:52-53

Bray NJ, O'Donovan MC (2019) The genetics of neuropsychiatric disorders. Brain Neurosci Adv. https://doi.org/10.1177/2398212818 799271

Bunzow JR (2001) Amphetamine, 3,4-methylenedioxymethamphetamine, lysergic acid diethylamide, and metabolites of catecholamine neurotransmitters are agonists of a rat trace amine receptor. Mol Pharmacol. https://doi.org/10.1124/mol.60.6.1181

Cao Q et al (1997) Suggestive evidence for a schizophrenia susceptibility locus on chromosome $6 \mathrm{q}$ and a confirmation in an independent series of pedigrees. Genomics 43:1-8. https://doi. org/10.1006/geno.1997.4815

Chang HS et al (2015) Association between TAAR6 polymorphisms and airway responsiveness to inhaled corticosteroids in asthmatic patients. Pharmacogenet Genom 25:334-342. https://doi. org/10.1097/FPC.0000000000000141

Cook JV, Eidne KA (1997) An intramolecular disulfide bond between conserved extracellular cysteines in the gonadotropinreleasing hormone receptor is essential for binding and activation. Endocrinology 138:2800-2806. https://doi.org/10.1210/ endo.138.7.5233

Cook JV, McGregor A, Lee T, Milligan G, Eidne KA (1996) A disulfide bonding interaction role for cysteines in the extracellular domain of the thyrotropin-releasing hormone receptor. Endocrinology 137:2851-2858. https://doi.org/10.1210/endo.137.7.8770906

de Jesus Ascencio-Montiel I, Pinto D, Parra EJ, Valladares-Salgado A, Cruz M, Scherer SW (2017) Characterization of large copy number variation in mexican type 2 diabetes subjects. Sci Rep 7:17105. https://doi.org/10.1038/s41598-017-17361-7

Dewan A, Pacifico R, Zhan R, Rinberg D, Bozza T (2013) Non-redundant coding of aversive odours in the main olfactory pathway. Nature 497:486-489. https://doi.org/10.1038/nature12114

Dick DM et al (2003) Genomewide linkage analyses of bipolar disorder: a new sample of 250 pedigrees from the National Institute of Mental Health Genetics Initiative. Am J Hum Genet 73:107-114. https://doi.org/10.1086/376562

Dohlman HG, Caron MG, DeBlasi A, Frielle T, Lefkowitz RJ (1990) Role of extracellular disulfide-bonded cysteines in the ligand binding function of the beta 2-adrenergic receptor. Biochemistry 29:2335-2342. https://doi.org/10.1021/bi00461a018

Duan J et al (2004) Polymorphisms in the trace amine receptor 4 (TRAR4) gene on chromosome 6q23.2 are associated with susceptibility to schizophrenia. Am J Hum Genet 75:624-638. https ://doi.org/10.1086/424887

Duan S et al (2006) Failure to find association between TRAR4 and schizophrenia in the Chinese Han population. J Neural Transm (Vienna) 113:381-385. https://doi.org/10.1007/s0070 2-005-0335-z

Escamilla MA, Zavala JM (2008) Genetics of bipolar disorder Dialogues. Clin Neurosci 10:141-152

Eyun SI (2018) Accelerated pseudogenization of trace amine-associated receptor genes in primates. Genes Brain Behav. https://doi. org/10.1111/gbb.12543

Eyun SI, Moriyama H, Hoffmann FG, Moriyama EN (2016) Molecular evolution and functional divergence of trace amine-associated receptors. PLoS ONE 11:e0151023. https://doi.org/10.1371/journ al.pone. 0151023
Ferrero DM et al (2011) Detection and avoidance of a carnivore odor by prey. Proc Natl Acad Sci USA 108:11235-11240. https://doi. org/10.1073/pnas.1103317108

Ferrero DM, Wacker D, Roque MA, Baldwin MW, Stevens RC, Liberles SD (2012) Agonists for 13 trace amine-associated receptors provide insight into the molecular basis of odor selectivity. ACS Chem Biol 7:1184-1189. https://doi.org/10.1021/cb300111e

Gainetdinov RR, Hoener MC, Berry MD (2018) Trace amines and their receptors. Pharmacol Rev 70:549-620. https://doi.org/10.1124/ pr.117.015305

Geracitano R, Federici M, Prisco S, Bernardi G, Mercuri NB (2004) Inhibitory effects of trace amines on rat midbrain dopaminergic neurons. Neuropharmacology 46:807-814. https://doi. org/10.1016/j.neuropharm.2003.11.031

Grandy DK (2007) Trace amine-associated receptor 1-Family archetype or iconoclast? Pharmacol Ther 116:355-390. https://doi. org/10.1016/j.pharmthera.2007.06.007

Grossberg S (2000) The imbalanced brain: from normal behavior to schizophrenia. Biol Psychiatry 48:81-98

Hashiguchi Y, Nishida M (2007) Evolution of trace amine associated receptor (TAAR) gene family in vertebrates: lineage-specific expansions and degradations of a second class of vertebrate chemosensory receptors expressed in the olfactory epithelium. Mol Biol Evol 24:2099-2107. https://doi.org/10.1093/molbev/msm140

Hoefig CS, Zucchi R, Kohrle J (2016) Thyronamines and derivatives: physiological relevance, pharmacological actions and future research directions. Thyroid 26:1656

Hu LA, Zhou T, Ahn J, Wang S, Zhou J, Hu Y, Liu Q (2009) Human and mouse trace amine-associated receptor 1 have distinct pharmacology towards endogenous monoamines and imidazoline receptor ligands. Biochem J 424:39-45. https://doi.org/10.1042/ BJ20090998

Huang JY et al (2016) Functional genomic analyses identify pathways dysregulated in animal model of autism. CNS Neurosci Ther 22:845-853. https://doi.org/10.1111/cns. 12582

Ikeda M et al (2005) No association of haplotype-tagging SNPs in TRAR4 with schizophrenia in Japanese patients. Schizophr Res 78:127-130. https://doi.org/10.1016/j.schres.2005.05.002

Ivleva EI et al (2017) Brain structure biomarkers in the psychosis biotypes: findings from the bipolar-schizophrenia network for intermediate phenotypes. Biol Psychiatry 82:26-39. https://doi. org/10.1016/j.biopsych.2016.08.030

Jaber L, Bailey-Wilson JE, Haj-Yehia M, Hernandez J, Shohat M (1994) Consanguineous matings in an Israeli-Arab community. Arch Pediatr Adolesc Med 148:412-415

Jaber L, Halpern GJ, Shohat T (2000) Trends in the frequencies of consanguineous marriages in the Israeli Arab community. Clin Genet 58:106-110

John J, Kukshal P, Bhatia T, Chowdari KV, Nimgaonkar VL, Deshpande SN, Thelma BK (2017) Possible role of rare variants in Trace amine associated receptor 1 in schizophrenia. Schizophr Res 12:158. https://doi.org/10.1016/j.schres.2017.02.020

Jones AV et al (2017) GWAS of self-reported mosquito bite size, itch intensity and attractiveness to mosquitoes implicates immunerelated predisposition loci. Hum Mol Genet 26:1391-1406. https ://doi.org/10.1093/hmg/ddx036

Kaufmann CA et al (1998) NIMH genetics initiative millenium schizophrenia consortium: linkage analysis of african-american pedigrees. Am J Med Genet 81:282-289

Kety SS, Wender PH, Jacobsen B, Ingraham LJ, Jansson L, Faber B, Kinney DK (1994) Mental illness in the biological and adoptive relatives of schizophrenic adoptees. Replication of the copenhagen study in the rest of Denmark. Arch Gen Psychiatry 51:442-455 
Kohrle J, Biebermann H (2019) 3-Iodothyronamine-A thyroid hormone metabolite with distinct target profiles and mode of action. Endocr Rev 40:602-630. https://doi.org/10.1210/er.2018-00182

Lagos-Quintana M, Rauhut R, Yalcin A, Meyer J, Lendeckel W, Tuschl $\mathrm{T}$ (2002) Identification of tissue-specific microRNAs from mouse. Curr Biol 12:735-739

Lander E, Kruglyak L (1995) Genetic dissection of complex traits: guidelines for interpreting and reporting linkage results. Nat Genet 11:241-247. https://doi.org/10.1038/ng1195-241

Lander ES, Schork NJ (1994) Genetic dissection of complex traits. Science 265:2037-2048. https://doi.org/10.1126/science.8091226

Lerer B et al (2003) Genome scan of Arab Israeli families maps a schizophrenia susceptibility gene to chromosome $6 \mathrm{q} 23$ and supports a locus at chromosome 10q24. Mol Psychiatry 8:488-498. https://doi.org/10.1038/sj.mp.4001322

Levi A et al (2005) Fine mapping of a schizophrenia susceptibility locus at chromosome 6q23: increased evidence for linkage and reduced linkage interval. Eur J Hum Genet 13:763-771. https:// doi.org/10.1038/sj.ejhg.5201406

Levinson DF et al (2000) Multicenter linkage study of schizophrenia candidate regions on chromosomes $5 \mathrm{q}, 6 \mathrm{q}, 10 \mathrm{p}$, and 13q: schizophrenia linkage collaborative group III. Am J Hum Genet 67:652-663. https://doi.org/10.1086/303041

Lindemann L, Ebeling M, Kratochwil NA, Bunzow JR, Grandy DK, Hoener MC (2005) Trace amine-associated receptors form structurally and functionally distinct subfamilies of novel $\mathrm{G}$ protein-coupled receptors. Genomics 85:372-385. https://doi. org/10.1016/j.ygeno.2004.11.010

Lindholm E et al (2001) A schizophrenia-susceptibility locus at 6q25, in one of the world's largest reported pedigrees. Am J Hum Genet 69:96-105. https://doi.org/10.1086/321288

Liu X, Grandy DK, Janowsky A (2014) Ractopamine, a livestock feed additive, is a full agonist at trace amine-associated receptor 1. J Pharmacol Exp Ther 350:124-129. https://doi.org/10.1124/ jpet.114.213116

Ludewick HP, Schwab SG, Albus M, Lerer B, Maier W, Trixler M, Wildenauer DB (2008) No support for an association with TAAR6 and schizophrenia in a linked population of European ancestry. Psychiatr Genet 18:208-210. https://doi.org/10.1097/YPG.0b013 e3283050aba

Maguire JJ, Parker WA, Foord SM, Bonner TI, Neubig RR, Davenport AP (2009) international union of pharmacology. LXXII. Recommendations for trace amine receptor nomenclature. Pharmacol Rev 61:1-8. https://doi.org/10.1124/pr.109.001107

Martinez M et al (1999) Follow-up study on a susceptibility locus for schizophrenia on chromosome 6q. Am J Med Genet 88:337-343

McInnis MG et al (2003) Genome-wide scan and conditional analysis in bipolar disorder: evidence for genomic interaction in the National Institute of Mental Health genetics initiative bipolar pedigrees. Biol Psychiatry 54:1265-1273

Merikangas KR et al (2011) Prevalence and correlates of bipolar spectrum disorder in the world mental health survey initiative. Arch Gen Psychiatry 68:241-251. https://doi.org/10.1001/archgenpsy chiatry.2011.12

Middleton FA et al (2004) Genomewide linkage analysis of bipolar disorder by use of a high-density single-nucleotide-polymorphism (SNP) genotyping assay: a comparison with microsatellite marker assays and finding of significant linkage to chromosome 6q22. Am J Hum Genet 74:886-897. https://doi.org/10.1086/420775

Miller GM et al (2005) Primate trace amine receptor 1 modulation by the dopamine transporter. J Pharmacol Exp Ther 313:983-994. https://doi.org/10.1124/jpet.105.084459

Muhlhaus J et al (2017) Investigation of naturally occurring singlenucleotide variants in human TAAR1. Front Pharmacol 8:807. https://doi.org/10.3389/fphar.2017.00807
Nowakowska B (2017) Clinical interpretation of copy number variants in the human genome. J Appl Genet 58:449-457. https://doi. org/10.1007/s13353-017-0407-4

Pae CU et al (2008a) TAAR6 variation effect on clinic presentation and outcome in a sample of schizophrenic in-patients: an open label study. Eur Psychiatry 23:390-395. https://doi.org/10.1016/j. eurpsy.2008.04.004

Pae CU et al (2008b) Association of the trace amine associated receptor 6 (TAAR6) gene with schizophrenia and bipolar disorder in a Korean case control sample. J Psychiatr Res 42:35-40. https:// doi.org/10.1016/j.jpsychires.2006.09.011

Pae CU, Drago A, Mandelli L, De Ronchi D, Serretti A (2009a) TAAR 6 and HSP-70 variations associated with bipolar disorder. Neurosci Lett 465:257-261. https://doi.org/10.1016/j.neule t.2009.09.025

Pae CU, Drago A, Patkar AA, Jun TY, Serretti A (2009b) Epistasis between a set of variations located in the TAAR6 and HSP70 genes toward schizophrenia and response to antipsychotic treatment. Eur Neuropsychopharmacol 19:806-811. https://doi. org/10.1016/j.euroneuro.2009.07.001

Pae CU, Drago A, Kim JJ, Patkar AA, Jun TY, De Ronchi D, Serretti A (2010) TAAR6 variations possibly associated with antidepressant response and suicidal behavior. Psychiatry Res 180:20 24. https://doi.org/10.1016/j.psychres.2009.08.007

Park TJ et al (2014) Genome-wide association study identifies ALLC polymorphisms correlated with FEV(1) change by corticosteroid. Clin Chim Acta 436:20-26. https://doi.org/10.1016/j. cca.2014.04.023

Parker EM, Cubeddu LX (1986) Effects of d-amphetamine and dopamine synthesis inhibitors on dopamine and acetylcholine neurotransmission in the striatum. II.Release in the presence of vesicular transmitter stores. J Pharmacol Exp Ther 237:193-203

Peltonen L, Palotie A, Lange K (2000) Use of population isolates for mapping complex traits. Nat Rev Genet 1:182-190. https:// doi.org/10.1038/35042049

Perlman JH, Wang W, Nussenzveig DR, Gershengorn MC (1995) A disulfide bond between conserved extracellular cysteines in the thyrotropin-releasing hormone receptor is critical for binding. J Biol Chem 270:24682-24685. https://doi.org/10.1074/ jbc.270.42.24682

Pierce KL, Premont RT, Lefkowitz RJ (2002) Seven-transmembrane receptors. Nat Rev Mol Cell Biol 3:639-650. https://doi. org/10.1038/nrm908

Redon R et al (2006) Global variation in copy number in the human genome. Nature 444:444-454. https://doi.org/10.1038/natur e05329

Reed C et al (2017) A spontaneous mutation in Taar1 impacts methamphetamine-related traits exclusively in DBA/2 mice from a single vendor. Front Pharmacol 8:993. https://doi.org/10.3389/ fphar.2017.00993

Risch N (1990) Linkage strategies for genetically complex traits. I.Multilocus models. Am J Hum Genet 46:222-228

Rutigliano G, Accorroni A, Zucchi R (2017) The case for TAAR1 as a modulator of central nervous system function. Front Pharmacol 8:987. https://doi.org/10.3389/fphar.2017.00987

Rutkowski TP, Schroeder JP, Gafford GM, Warren ST, Weinshenker D, Caspary T, Mulle JG (2017) Unraveling the genetic architecture of copy number variants associated with schizophrenia and other neuropsychiatric disorders. J Neurosci Res 95:1144-1160. https://doi.org/10.1002/jnr.23970

Sanders AR et al (2008) No significant association of 14 candidate genes with schizophrenia in a large European ancestry sample: implications for psychiatric genetics. Am J Psychiatry 165:497506. https://doi.org/10.1176/appi.ajp.2007.07101573

Savarese TM, Wang CD, Fraser CM (1992) Site-directed mutagenesis of the rat $\mathrm{m} 1$ muscarinic acetylcholine receptor. Role 
of conserved cysteines in receptor function. J Biol Chem 267:11439-11448

Scanlan TS et al (2004) 3-Iodothyronamine is an endogenous and rapid-acting derivative of thyroid hormone. Nat Med 10:638642. https://doi.org/10.1038/nm1051

Schwab SG et al (2000) A genome-wide autosomal screen for schizophrenia susceptibility loci in 71 families with affected siblings: support for loci on chromosome 10p and 6. Mol Psychiatry 5:638-649

Schwartz MD, Canales JJ, Zucchi R, Espinoza S, Sukhanov I, Gainetdinov RR (2018) Trace amine-associated receptor 1: a multimodal therapeutic target for neuropsychiatric diseases. Expert Opin Ther Targets 22:513-526. https://doi.org/10.1080/14728 222.2018 .1480723

Shahin MH et al (2018) Genome-wide association approach identified novel genetic predictors of heart rate response to beta-blockers. J Am Heart Assoc. https://doi.org/10.1161/ JAHA. 117.006463

Shi X et al (2016) Genetic polymorphisms affect mouse and human trace amine-associated receptor 1 function. PLoS ONE 11:e0152581. https://doi.org/10.1371/journal.pone.0152581

Simmler LD, Buchy D, Chaboz S, Hoener MC, Liechti ME (2016) In vitro characterization of psychoactive substances at rat, mouse, and human trace amine-associated receptor 1. J Pharmacol Exp Ther 357:134-144. https://doi.org/10.1124/jpet.115.229765

Smith SB et al (2012) Large candidate gene association study reveals genetic risk factors and therapeutic targets for fibromyalgia. Arthritis Rheum 64:584-593. https://doi.org/10.1002/art.33338

Smoller JW, Andreassen OA, Edenberg HJ, Faraone SV, Glatt SJ, Kendler KS (2019) Psychiatric genetics and the structure of psychopathology. Mol Psychiatry 24:409-420. https://doi. org/10.1038/s41380-017-0010-4

Staubert C, Boselt I, Bohnekamp J, Rompler H, Enard W, Schoneberg $\mathrm{T}$ (2010) Structural and functional evolution of the trace amineassociated receptors TAAR3, TAAR4 and TAAR5 in primates. PLoS ONE 5:e11133. https://doi.org/10.1371/journal.pone.00111 33

Sukhanov I, Espinoza S, Yakovlev DS, Hoener MC, Sotnikova TD, Gainetdinov RR (2014) TAAR1-dependent effects of apomorphine in mice. Int J Neuropsychopharmacol 17:1683-1693. https ://doi.org/10.1017/S1461145714000509
Szekely E et al (2018) Genetic associations with childhood brain growth, defined in two longitudinal cohorts. Genet Epidemiol 42:405-414. https://doi.org/10.1002/gepi.22122

Venken T et al (2005) Genomewide scan for affective disorder susceptibility Loci in families of a northern Swedish isolated population. Am J Hum Genet 76:237-248. https://doi.org/10.1086/427836

Venken T, Alaerts M, Adolfsson R, Broeckhoven CV, Del-Favero J (2006) No association of the trace amine-associated receptor 6 with bipolar disorder in a northern Swedish population. Psychiatr Genet 16:1-2

Vladimirov V et al (2007) A region of $35 \mathrm{~kb}$ containing the trace amine associate receptor 6 (TAAR6) gene is associated with schizophrenia in the Irish study of high-density schizophrenia families. Mol Psychiatry 12:842-853. https://doi.org/10.1038/sj.mp.4001984

Vladimirov VI, Maher BS, Wormley B, O'Neill FA, Walsh D, Kendler KS, Riley BP (2009) The trace amine associated receptor (TAAR6) gene is not associated with schizophrenia in the Irish case-control study of Schizophrenia (ICCSS) sample. Schizophr Res 107:249-254. https://doi.org/10.1016/j.schres.2008.09.030

Xi L, Junjian Z, Yumin L, Yunwen L, Hongbin W (2009) Serum biomarkers of vascular cognitive impairment evaluated by beadbased proteomic technology. Neurosci Lett 463:6-11. https://doi. org/10.1016/j.neulet.2009.07.056

Yang J et al (2018) Peptidome analysis reveals novel serum biomarkers for children with autism spectrum disorder in China. Proteom Clin Appl 12:e1700164. https://doi.org/10.1002/prca.201700164

Zucchi R, Chiellini G, Scanlan TS, Grandy DK (2006) Trace amineassociated receptors and their ligands. Br J Pharmacol 149:967978. https://doi.org/10.1038/sj.bjp.0706948

Zucchi R, Accorroni A, Chiellini G (2014) Update on 3-iodothyronamine and its neurological and metabolic actions. Front Physiol 5:402. https://doi.org/10.3389/fphys.2014.00402

Publisher's Note Springer Nature remains neutral with regard to jurisdictional claims in published maps and institutional affiliations. 